\title{
THE ACTIVITIES OF FR FRIEDRICH MUCKERMANN IN 1918-1919 IN VILNIUS: \\ A SIGNIFICANT APPLICATION TOWARDS \\ A CIVIL SOCIETY? (THE PHENOMENON OF THE CHRISTIAN WORKERS LEAGUE)
}

\author{
Edmundas Gimžauskas
}

\begin{abstract}
The activities of the German priest Friedrich Muckermann in Vilnius would belong to those cases when an extraordinary personality influenced crucially the development of the public process, by rallying an abundant crowd of followers. The assumptions of the social activities initiated by this Jesuit priest consisted of the transformation of the Catholic Church at the beginning of the 20th century from a confessional to a social category, and the conditioned general operation of the latter phenomenon. At the turn of 1918-1919 in Vilnius, due to the efforts of Muckermann, the League of Christian Workers appeared and gained more and more popularity in lower social strata. This seriously worried the Bolshevik government. Activists of the national movements conflicting with each other, in turn, understanding the prospects for the cultural-social consolidation begun by the priest to become political, naturally sought to influence the League. The arrest of Muckermann by the Bolsheviks not only encouraged a shift by the League to the Polish side, but also changed the nature of the organisation in the direction of radical action. Members of the League contributed actively to the capture of Vilnius by the Polish army in April 1919. And from that time, the organisation can be considered to be Polish, which in no way could be said about the League run by Muckermann. Leaving Bolshevik captivity at the end of 1919 in an exceptional way, he became not only a famous Catholic activist in interwar Germany, but also a symbol of the Christian resistance to Nazism.
\end{abstract}

The activities of Fr Friedrich Muckermann and his followers at the turn of 1918-1919 undoubtedly significantly stirred the public of Vilnius at the time, and for a while became one of its most important current affairs. This is testified to by the written legacy of witnesses and contemporaries (representing different social and 
political provisions) of these activities. ${ }^{1}$ However, in 'traditional' general histories in which the section on the development of Vilnius in this period is analysed, and from which the general public usually draws its information, the activities mentioned are usually left out by historians. Usually the axis of such studies on the period covered is the tussle for power by representatives of national movements, imperial forces and the followers of Bolshevism in the city government. Because the activities of the priest and his supporters are not easily fitted into this scene, and in some cases may even be inconvenient to the prevailing historiographical opinions, they are just left 'overboard'. Thus, the activities of Muckermann in Vilnius remain in general poorly covered in current scholarship. He has won attention only in circles of Church history specialists. The latter, as a rule, have tapped into the activities of Muckermann only in the broader context of the Catholic Church in the biography of Bd Archbishop Jurgis Matulaitis Matulevičius. ${ }^{2}$ Nevertheless, in recent times, the 'history of Muckermann' resonated in the works of several Polish authors dealing with research into the history of Vilnius. ${ }^{3}$ Characteristically, in these works, the approach to the activities of the famous priest is not through his

${ }^{1}$ P. Bieliauskas, Vilniaus dienoraštis 1915. XII. 26-1919. XI. 26 (Trakai, 2009), pp. 136-137; M. Biržiška, Dèl mūsu sostinès (Iš Vilniaus darbo atsiminimu), d. 1 (London, 1960), pp. 69-70, 97; V. Kapsukas, Raštai, t. 8, (Vilnius, 1966), pp. 211-212; K. Okulicz, Brzask, dzień i zmierzch na ziemiach Litwy historycznej, Pamiętnik wileński (London-Łomianki, 2010), s. 45; B. Waligóra, Walka o Wilno. Okupacja Litwy i Białorusi w 1918-1919 r. przez Rosje Sowiecka (Wilno, 1938), pp. 122-125, 145-151; also a great number of brief news items about events in the periodicals of that time (the most significant ones were used in the research). Nevertheless, Bishop J. Matulaitis has left the most comprehensive text about the activities of Fr. Muckermann and his organisation: J. Matulaitis, Užrašai, ed. P. Subačius (Vilnius, 1998), pp. 137-148, 155-157.

2 J. Boruta, SJ, 'Palaimintasis Jurgis Matulaitis - Šv. Kazimiero bažnyčios atkūrèjas 1919 m.', Lietuviu kataliku mokslo akademijos metraštis 25 (2004), pp. 331-343; G. Gustaite, 'Kaip vysk. Jurgis Matulaitis gelbejo t. Frydrichą Mukermaną' ibid., 21 (2002), pp. 607- 612; T. Górski, MIC, Palaimintasis Jurgis Matulaitis (Kaunas, 2009), pp. 159-163.

${ }^{3}$ P. Dąbrowski, Rozpolitykowane miasto: ustrój polityczny państwa $w$ koncepcjach polskich ugrupowań działających w Wilnie w latach 1918-1939 (Gdańsk, 2012), pp. 55-64; L. Narkowicz, Jan Konrad Obst - publicysta, wydawca, historyk (1876-1954) (Bydgoszcz, 2004), pp. 201-210; eadem, 'Liga Robotnicza Św. Kazimierza - stowarzyszenie oświatowo-ekonomiczne', Studium Vilnense. A, vol. 1, no. 1 (Vilnius, 2003), pp. 434-437; Gimnazjum Ojców Jezuitów w Wilnie w latach 1922-1940, pod red. L.J. Malinowskiego (Bydgoszcz, 1999), pp. 36-37, 49. 
person, but through a presentation of the organisation he founded, the League of Workers. ${ }^{4}$ The greatest merit of these works would be that for the first time in current historiography the League of Workers received individual attention.

However, the picture of the events of that time drawn in Polish works is quite different from the understanding which we form reading the works of Church historians. The most characteristic of the first trend is that the League of Workers is portrayed as a simple Polish organisation from the moment of its establishment. And this contrasts markedly not only with the information provided by Church historians, but also the material of the original source, on which Church historians rely the most, the Užrašai (Notes) of Archbishop Matulaitis. Hence, it would be totally justifiable to consider the story provided in some Polish works as biased, or even as a distortion of the historical truth. Not least because of this, it would be important and relevant to look anew and in more detail at the episode of the work of Muckermann and the League of Workers. Looking from the position of Lithuanian historiography, simply the necessity is ripe for introducing the episode of the activities of the League of Workers and its founder into the overall context of Lithuania's historical development.

The organiser of the League of Workers and the role of its first and most prominent leader is unanimously recognised as Fr Muckermann; no one questions this fact. All the interpretations begin immediately afterwards. However, at the beginning, it would be worth distinguishing several, in our opinion, points made in memoirs and historiography touching on the professional activities of the prominent priest in Vilnius which would help to understand better the essence and development of the organisation he founded. These professional subjects are the following: Muckermann as a Jesuit, as the administrator of St Casimir's Church, and as the head of the League of Workers. Although we are most interested in the latter aspect, it can be fully understood, however, only in the light of the first two.

${ }^{4}$ The original name of the organisation in Polish was Liga Robotnicza Św. Kazimierza. The historian G. Gustaite uses the term Christian Workers Union. P. Subačius, who prepared Užrašai by J. Matulaitis, translates the Polish name as the Saint Casimir Workers League. Matulaitis himself in his Užrašai used the name Krikščioniu darbininku Sanjunga. In this paper, for the sake of convenience, we will use the term League of Workers, or simply League. 
Friedrich Muckermann arrived in Vilnius, which was ruled by the German military administration, on 20 June $1918 .{ }^{5}$ He then served as a Catholic chaplain in the German army. Muckermann was born in 1883 in Bückeburg. His father Hermann Muckermann was a merchant, engaged in the footwear trade. His mother Anna Rüther was deeply religious, and had nine children (five of whom later joined the Jesuits). Friedrich studied in high schools in Bücheburg and Padeborn, and later in 1899 he entered the Jesuit novitiate in Valkenburg, in the Netherlands. In 1901-1903 he served in the army, and after returning he studied philosophy at Valkenburg. He completed his intersticium at Jesuit colleges in Feldkirch (Austria) and Ordrupskoje (Denmark). In 1909-1912 he studied German and pedagogy at the University of Copenhagen, and then began his theological studies in Valkenburg. After the war began in 1914, not having finished his studies yet, he was ordained a priest. He served on the Western Front as an orderly, and at the end of the year he was sent to the Eastern Front as a military chaplain. ${ }^{6}$

An assistant, Marcin Malik, also belonging to the Jesuits, came to Vilnius along with him. ${ }^{7}$ In Vilnius, meanwhile, as is known, there was a strong Jesuit tradition from the old days. St Casimir's Church, built by the Jesuits, was taken away from Catholics by the Russian government in 1832 and given to Orthodox believers. In 1915 the Germans took it over for the spiritual needs of its soldiers. It is not fully clear how Protestant and Catholic rites were coordinated in it, or if at the beginning only Protestant services took place, because the keys of the church belonged to the Protestant pastor. After the arrival of Muckermann and his assistant, without doubt, in his work as a chaplain, he tried also to represent the interests of the Jesuits. Meanwhile, as the end of the war was approaching, he increasingly encouraged a return to traditional religious activities and priorities. Thus, in the autumn of 1918, especially after the November Revolution in Germany, these Jesuits who found themselves in Vilnius due

${ }^{5}$ Gimnazjum Ojców Jezuitów w Wilnie, p. 37.

${ }^{6}$ H. Gruber, Friedrich Muckermann SJ, Stimmen der Zeit, 1996 April, Heft 4, S. 266; Biographisches Handbuch der deutschsprachigen Emigration nach 1933, Bd. 1, ed. S. Claus und B. Schmidt (Munich, 1999), p. 510; cf. J. Boruta, Palaimintasis Jurgis Matulaitis, p. 335. Polish authors mention that Muckermann's mother was of Polish origin, and relate this to the priest's decision to stay in Vilnius (Gimnazjum Ojców Jezuitów w Wilnie, p. 37, L. Narkowicz, Jan Konrad Obst, s. 201), but German biographers do not mention this fact.

${ }^{7}$ Gimnazjum Ojców Jezuitów w Wilnie, p. 37. 
to the circumstances of the war, seeing the favourable development of circumstances, decided to try to return St Casimir's Church and the adjacent buildings once owned by the Jesuits to the Catholic Church and at the same time to his order. The keys were obtained from the Pastor, and, as Polish authors note, on 25 November, after a break of many years, the first Catholic Mass was celebrated in the church. ${ }^{8}$ Taking the whole context into account, it seems that the Polish authors here were not completely right: most likely this was the first Mass which civilians could attend freely. Informed about this, the Jesuit provincial Heinrich F. Haduch appointed Muckermann the superior of the Vilnius house. ${ }^{9}$

However, threats to the beginning activities very quickly emerged. Feeling the changes of authorities, the Orthodox clergy again pursued their claims to the church. They began writing complaints to the secular and spiritual authorities, and even tried to organise an invasion of the church by force. ${ }^{10}$ However, the main threat became the approaching armed Bolshevism from the East. It seems that this even forced Muckermann at some point to question the further prospects of their activities. But then again, it happened that at that time Jurgis Matulaitis-Matulevičius was appointed Bishop of Vilnius, who supported and encouraged the intentions of the German priest.

Matulaitis was consecrated bishop on 1 December 1918 in Kaunas, and on 8 December his ingress ceremony was held in Vilnius. ${ }^{11}$ We should recall that before his appointment as bishop, Matulaitis was not too well known by the general public. Coming from Lithuanian Suwalki, but having completed his theological studies in Poland, Switzerland and St Petersburg, the former professor and vice-rector of the Kielce Seminary, was maybe better known not in a Lithuanian but a Polish environment. ${ }^{12}$ It is important to note that he was an active proponent and implementer of the programme announced in the encyclical 'Rerum novarum' of Pope Leo XIII in 1891, in which he advocated social peace and harmony. This attitude, as became clear later, had a significant positive value for the Vilnius region, where social and national problems were closely intertwined. Looking at the positions of the current time, and emphasising not so much

\footnotetext{
${ }^{8}$ Ibid., pp. 37, 49.

${ }^{9}$ Ibid., p. 37.

${ }^{10}$ For more see: Boruta, 'Palaimintasis Jurgis Matulaitis', pp. 333-336.

${ }^{11}$ Matulaitis, Užrašai, pp. 108-115.

${ }^{12}$ For more information see: Górski, Palaimintasis Jurgis Matulaitis.
} 
the purely religious, but the social side of the phenomenon, we could say that the residents of Vilnius at the end of 1918 received not only a diligent and, as far as possible, impartial shepherd, but first of all a specialist in Christian social teaching, a theoretician of Christian Democracy.

Immediately after his appointment, the Orthodox clergy again appealed to the bishop, requesting the return of St Casimir's Church to them. The bishop diplomatically directed them to appeal to the German administration, but also advised them not to irritate the Catholic faithful for whom visiting the church was becoming ever more popular. According to the bishop, 'our people, remembering the ancient past, also began to attend this little church in flocks.' ${ }^{13}$ Matulaitis also wrote 'I am very concerned that after the Germans leave it does not slip out of Catholic hands. ${ }^{14}$ Therefore, he personally asked Muckermann not to leave with the retreating German army, and remain in Vilnius. He also promised to give the church to the Jesuits if they were able to defend it. This probably determined the decision of the German priest. Matulaitis mentions that 'I gave him one more priest to help him. Mass was said beautifully in the church, many people would gather. ${ }^{15}$ In this way, in the first days of January 1919, the Bolshevik period came to Vilnius, and with it also began the history of the League of Workers.

With the arrival of the Bolsheviks, the importance of Christian activity increased. In terms of the global understanding at that time of the relationship between the individual Catholic and society, we have to note that Catholicism, in the context of nationalism and the modernisation of society, evolved from only a confessional conception into the totality of the spiritual, cultural, professional, charitable and political organisations beginning to be founded in the second half of the 19th century. A network of Catholic organisations initiated by Pope Leo XIII and implemented at the beginning by the clergy, seeking to cover the widest possible field of public life and to protect the faithful 'from the hardships of modernism', in which, in the understanding of the highest leaders of the Church, nationalism and the doctrine of liberalism and socialism were especially strengthened, began to

${ }^{13}$ Matulaitis, Užrašai, p. 137.

${ }^{14}$ Ibid.

${ }^{15}$ Ibid., p. 138. 
be formed. ${ }^{16}$ The content of public Catholicism consisted of the postulates arising from Rerum novarum and other papal encyclicals, such as the development of society according to natural and divine law, while guaranteeing the people the legal rights belonging to them, and also enabling the realisation of ethical and religious obligations. It also aimed to seek the development of the Christian spirit, state institutions whose main task had to be the assurance of the rights of workers, the rehabilitation of social-economic relations between the broad masses of people, the proclamation of slogans of equality, fraternity, charity, freedom and justice, and the constant improvement of quality. ${ }^{17}$ Therefore, only those governments which were not hostile to the Catholic Church and based their legislative projects on unconditional social honesty and justice had to be supported. There was also the aim that religion would be taught in every school, and that the rights of all religions would be made equal. Private property was recognised, but the flawed system of hired labour was attacked. These ideas spread, and first materialised in Western societies. They reached the Polish and Lithuanian lands greatly transformed, from the very beginning they were closely intertwined here with ideas of nationalism. As it would be parodoxical and strange in the Polish lands, Christian Democracy as a political force was not popular from the beginning. ${ }^{18}$ Its niche in the political spectrum was firmly occupied by the National Democrats (endeks). It only had some kind of success in urban societies. ${ }^{19}$ In the Lithuanian lands, as well as in the Vilnius region, due to Imperial Russian policy, Christian Democracy did not have possibilities for free development until the beginning of the First World War. Only in 1917 did the Lithuanian Christian Democratic Party begin to be created on a national basis. In the period at the end of the war, three directions of activity stood out in the activities of Christian Democracy in Vilnius: educationalcultural, economic and political. ${ }^{20}$ The last activity was within the framework of the Union of Polish Christian Democrats in Lithuania (Polski Zwiazek Chrzescijansko-Demokratyczny na Litwie), founded

\footnotetext{
${ }^{16}$ A. Svarauskas, Krikščioniškosios demokratijos idèjinè ir struktūrinè raida Lietuvos Respublikoje 1918-1940 m.: daktaro disertacija, Vilnius-Klaipėda, 2011, p. 5.

${ }^{17}$ P. Dąbrowski, Rozpolitykowane miasto, pp. 55-56.

${ }^{18}$ A. Svarauskas, Krikščioniškosios demokratijos raida, pp. 23, 33-34.

${ }^{19}$ M. Leczyk, Druga Rzeczpospolita 1918-1939. Spoleczeństwo, gospodarka,
} kultura, polityka (Warsaw, 2006), pp. 160-161.

${ }^{20}$ P. Dąbrowski, Rozpolitykowane miasto, p. 56. 
in October 1918 and led by Fr Ignacy Olszański. ${ }^{21}$ Its activity was mostly the publication and distribution of numerous propaganda leaflets and proclamations. The Catholic Association of Polish Workers (Stowarzyszenie Katolickie Robotników Polskich) carried out educational-cultural activities. However, the Christian trade unions, representing the direction of economic activity, had the most potential and value in the conditions of the Vilnius region, especially when the political activities of the German administration were limited and restricted. Fr Olszański is again mentioned among their main activists and organisers. ${ }^{22}$

As Bishop Matulaitis noted, 'After the Bolsheviks came, life seemed to pause. Fr Olszański, who headed the associations of Polish workers, initially had to hide'. And then 'Fr Muckermann came to discuss whether it would be possible to do something good for the workers. ${ }^{23}$ As the German clergyman himself mentions in his memoirs, the incentive for this move was the horror of the attitude and behaviour of Russia's Bolsheviks who had marched into Vilnius, as well as the concern that the atheist arrivals would devastate the Catholic city. ${ }^{24}$ Bishop Matulaitis continues: 'I asked Fr Muckermann to rely purely on the foundation of Catholicism, that he should carry out work for the sake of Catholicism, ignoring politics and national feeling. I said, as far as I know, if you, Sir, carry out purely Catholic work, then the work will progress; there is already enough of that nationality for everyone. It was decided that the goal of the work would be purely religious, cultural and material.'

Initially he tried to organise a conference for workers at about 5 p.m. on a Sunday afternoon. Many people assembled. Upon seeing this, he invited them into the empty house by the church and began organisational work. He called the new organization the Krikščionių Sajunga (Christian Union); people began to enrol en masse. ${ }^{25}$ In his memoirs, Muckermann provides an excerpt of his thoughts, expressed at the organisation's inaugural meeting: 'People, we are not socialists, we are Christians. Our goal is not to destroy, but to create. God forbid, no class struggle! No word of hate against anyone. Yes, as the Holy Father, the great Pope Leo XIII, indicated in

${ }^{21}$ Ibid., p. 57.

${ }^{22}$ Ibid., pp. 56-57.

${ }^{23}$ Matulaitis, Užrašai, p. 138.

${ }^{24}$ Muckermann, Wspomnienia z niewoli bolszewickiej (1922), pp. 4-5.

${ }^{25}$ Matulaitis, Užrašai, p. 138. 
his famous encyclical, so we have to understand mutual assistance in this way. Let us not bow to the golden calf, not sell our souls for money. The benefits of an increase in salary will be meagre if with it there is not a hand to hand rise in the level of education. ${ }^{26}$ These thoughts already suggest that Bishop Matulaitis found in the Rev Muckermann an ideological fellow traveller and the implementer and successor for his own mature ideas. Having acquired the education of a clergyman in a Western environment, Muckermann undoubtedly had a good understanding of Christian social activities, and, what was more important, he had the enthusiasm and passion to take up such challenges. In Germany, the first Catholic social ideas were raised by the Jesuit Emmanuel Kettel, Bishop of Mainz who in the 1840s preached unusual sermons for that time about the fact that the Church must rescue workers from impoverishment by capitalism, and not allow them to admire socialism. According to him, the Church's teaching was in the middle ground between the extremes of liberalism and socialism. He urged the clergy to take an active role in the social sphere, to organise organisations of social assistance and mutual aid, and to strive for the regulation of the state economy. ${ }^{27}$ So Muckermann, in the person of his fellow countryman and member of the order, might have had a certain tradition and a clear example to follow.

The official founding date of the League is 1 February $1919 .{ }^{28}$ From its very beginning, it was led by an organising committee, at the forefront of which stood Muckermann. According to him, after the first two weeks, the organisation already had 5,000 members, there was money in the treasury (every entrant paid a ruble and received a membership certificate), it had its own offices, and two halls for meetings, in each of which more than 2,000 people could be accommodated. ${ }^{29}$ Among the first needs was the establishment of a people's cafeteria and a cooperative. The most interesting and also the most sensitive question in historical studies is the question of the national composition of the members of the organisation; closely related to this is the question of the attitude of the League to political issues. Bishop Matulaitis has noted that the poorest, regardless

${ }^{26}$ Muckermann, Wspomnienia, p. 7.

${ }^{27}$ K. Paltarokas, Socialis klausimas (Kaunas, 1921), pp. 105-107.

${ }^{28}$ The date 1 February is emphasised by the Polish historian Liliana Narkowicz (L. Narkowicz, Jan Konrad Obst, p. 201; eadem, Liga Robotnicza Św. Kazimieza, p. 434).

${ }^{29}$ Muckermann, Wspomnienia, pp. 7-8. 
of nation, began to assemble in that union. ${ }^{30}$ Without a doubt, the Poles comprised the most numerous part of the Catholics, so it is logical to assume that they constituted the most numerous, or at least a very significant part of the League's members. Lithuanians also enrolled in the organisation, said at that time the openly independent newspaper of the Lithuanian Christian Democrats. ${ }^{31}$ From the fact that a Belarusian priest became one of its leaders, we can infer that Belarusian Catholics regarded it as their own. As for the Poles, it is important to note that their militant nationalism at the time due to the weakness and disorganisation of their defence against the Bolsheviks was dimmed. In the rhetoric of Church spheres, taking into account the political changes, the emphasis on the Polish identity also suddenly faded away, being replaced by an emphasis on fundamental Christian values. This led to a situation where at least for a moment, issues of national identity were no longer emphasised, and Lithuanians and Belarusians could feel like equal partners of the Poles in Christian activities. At the same time, in such a situation it could turn out very quickly that the positions of the Polish identity among the Catholics of Vilnius were not so unambiguously strong. After the Bolshevik government eliminated the influence on the masses of the Polish activists, many of the common people, in appropriate circumstances, could remember their Lithuanian or Belarusian roots. After all, Wanda Niedziałkowska-Dobaczewska, one of the pillars of the Vilnius Polish identity, said that at the end of 1918 'broad layers of Poles-Belarusians in the Vilnius region were a mass without any kind of national consciousness, but only longing for their pre-war prosperity, when there was as much bread as one desired and there was no forced work for the benefit of the Germans. ${ }^{32}$

Therefore, even the subdued Polish nationalists began to express their concern. Bishop Matulaitis noted that when the League began to be formed 'Fr Olszański did not like this work, several times he came to me to complain that his work was being disrupted.' At that time, the bishop found a compromise satisfying everyone: 'Fr Olszański can organise and lead the professional unions and carry out the cultural work, which he has, and Fr Muckermann can

${ }^{30}$ Matulaitis, Užrašai, p. 138.

${ }^{31}$ Katalikų darbininkų lyga, Tiesos kardas, 1919, Feb 21, no. 39, p. 2.

${ }^{32}$ W. Niedziałkowska-Dobaczewska, 'Rola kobiet wileńskich w akcji wyzwolenia Wilna', Wilno Wyzwolone. Jednodniówka na zjazd b. uczestnikow walk o Wilno w d. 10-11 listopada 1930 r. (Vilnius, 1930), p. 28. 
continue his spiritual, cultural and economic work; let his workers support the professional unions of Fr Olszański." ${ }^{33}$ The earlier-mentioned Belarusian priest in the Muckermann organisation was Mikalaj Pjatrovski. Matulaitis wrote: 'For assistance, I gave Fr Muckermann the Rev Petrauckas, a Belarusian; he knows well how to speak to the people, and is knowledgeable about social work.' 34

A permanent board, elected by all the members of the League at a general meeting, rapidly replaced the League's Organising Committee. The Board consisted of nine people, at the beginning. In addition to the already-mentioned Pjatrovski and Muckermann's fellow Jesuit Malik, Stefan Dowgiałłowiczius, Stanisław Górski, Jan Łokuciewskis (Łokuciejewskis), Jan Pietkiewiczius and Bolesław Nejman also belonged to it. ${ }^{35}$ The activities of the League were divided into separate sections, such as, for example, cooperative activities, 'high school of the people', a people's theatre and people's workshops. Appropriate individual commissions determined their activities. Cultural-educational activities were guided by the principle that 'education is not the privilege of a certain rich class', and therefore 'higher scholarly courses' were organised. The monthly subscription for them cost four rubles. Lectures were held daily, except Saturdays; both men and women attended them. The main facilities for the courses were the 'Ognisko' Hall (Bernardinu skersgatvis 8). The lecturers taught their audience information about geography and nature, Christian ethics and apologetics, human anatomy and physiology, botany, chemistry and agriculture, as well as philosophy, and Polish history, Polish and world literature. ${ }^{36}$ According to Muckermann, local intellectuals, especially teachers, gladly offered their services in this field. ${ }^{37}$ The theatre of the League used the facilities of the Polish Pohulianka Theatre. Its first staged spectacle immediately after its establishment was 'Girls' Night' (Dziewiczy wieczór) by Gabriela Zapolska. ${ }^{38}$ A library of the organisation and an amateur choir appeared. A school of the League and a youth hostel were founded.

However, in the circumstances of that time, satisfying the everyday needs of the lower social classes was the most important, and

\footnotetext{
${ }^{33}$ Matulaitis, Užrašai, pp. 138-139.

${ }^{34}$ Ibid., p. 138.

${ }^{35}$ Narkowicz, Liga Robotnicza, s. 434.

${ }^{36}$ Wyższe kursa naukowe, Głos ludu, 7 II 1919, no. 1, pp. 2-3.

${ }^{37}$ Muckermann, Wspomnienia, s. 8.

${ }^{38}$ Teatr Ligi Robotniczej, Głos ludu, 7 II 1919, no. 1, p. 2.
} 
here the weight and role of the League emerged the most. When fear, hunger and uncertainty reigned in the city, and the Bolsheviks requisitioned food products, and robbed homes and basements, the homeless found shelter in the buildings by the Jesuit church. Part of the facilities was given over to the needs of medical care, and the required medical assistance was organised. The most serious and most pressing matter was providing food. The introduction of the Bolshevik government in this area created considerable confusion. Several institutions (the Soviet of Vilnius workers, the Vilnius revkom [revolutionary committee], the provisions commissariat of the V. Kapsukas government) had to take care of supplying and feeding the population. ${ }^{39}$ But there was often no co-ordination of activities between them, and other causes were a hindrance. Although the Bolshevik authorities sent their purchasing agents into the province, this produced very poor results: the peasants, especially in areas where Lithuanians lived, did not trust the Soviet government, and did not rush to supply products; moreover, they did not want to sell for the depreciated 'kerenka' currency. Even some of the revkoms and ispolkoms of the province refused to satisfy the wishes of the central government, citing a possible food shortage in some areas. ${ }^{40}$ The forced means of the Bolsheviks for gathering food (requisitions, confiscations, etc) created confusion and frustration among dealers and small traders. Meanwhile, the Soviet authorities could not do without the services of the latter, because they had not yet created their own supply and distribution apparatus. All this constantly increased food prices. Bread prices doubled with the coming of the Bolshevik army, and by 5 February had increased by five or six times. ${ }^{41}$ In Vilnius during the years of the German occupation, a number of Polish and Jewish societies and institutions, whose task was the organisation of cheaper subsistence, were active. For example, the Polish Society of Less Expensive Kitchens established by Zygmunt Nagrodzki was significant. In late January, the Soviet of Vilnius Workers decided to take control of all these less expensive city kitchens and cafeterias from 1 February. The Poles defended their cafeterias by all means, and succeeded, arguing that they were not private property, but that of united people. ${ }^{42}$ The atmosphere was worsened by the fact that

\footnotetext{
${ }^{39}$ Waligóra, Walka o Wilno, p. 140.

${ }^{40}$ Ibid., p. 143.

${ }^{41}$ Ibid., p. 142.

42 Ibid., pp. 140, 143-144.
} 
these cafeterias carried out not only the function of feeding, but were also certain cultural-educational centres, and fighting for their takeover or maintenance had a primarily political meaning. The situation of similar institutions of the Jewish community for acquiring products was better, because the Jews were the main agents in the purchases of the Soviet government.

Under these circumstances, the League of Workers began the establishment of its own kitchen and cooperative. The plans in this area were quite ambitious. According to Muckermann, 'because communication with the countryside was almost stopped, and the arrival of products was poor and irregular, we designed the creation of institutions for special trade that would mediate between the city and the country'. The cooperative was needed 'due to the complete Jewish domination of trade. ${ }^{43}$ In every parish, it was intended to set up committees in which all League members would be able to acquire potatoes and vegetables at reduced prices. ${ }^{44}$

And again, according to Muckermann, when the cafeteria opened and 'our pots boiled with tasty steam, and every day the Soviet soup became more and more watery, people from the opposite camp began to visit us more frequently.' 45 Of course, all this could not go unnoticed by the top Bolshevik government. Sensing that he was drawing attention, Muckermann decided to visit government officials and explore the possible actions. ${ }^{46}$ It was emphasised to the government that the League cared for the well-being of workers by creating cafeterias, co-operatives; it was emphasised that economic and cultural-educational matters were pursued. The Bolsheviks, in turn, promised to look more closely into the activities of the organisation. And on the next Sunday, after Mass, the superintendent of the city visited the meeting of the organisation in the church. He did not find anything to reproach: Muckermann's assistants quickly improvised a rally, at which slogans demanding cheap bread, ending the war, and so on, resounded. ${ }^{47}$

The commandant was forced to admit that this was a meeting of the proletariat, and the League was left alone for a while. However, government agents attended the organisation's events and followed

\footnotetext{
${ }^{43}$ Kataliku darbininkų lyga, Tiesos kardas, 21 February 1919, no. 39, p. 2.

${ }^{44}$ Muckermann, Wspomnienia, s. 8.

${ }^{45}$ Ibidem.

${ }^{46}$ Ibid., p. 9.

${ }^{47}$ Ibid., pp. 9-10; B. Waligóra, Walka o Wilno, p. 124.
} 
its activities. For example, one of them on 20 January wrote down the thoughts expressed by Muckermann, and noted the statement that 'dreadful hurricanes are now approaching' and workers wanting to protect themselves should assemble in the church, where also from workers they will hear the real word of the truth. ${ }^{48}$

Soon the news spread through the city that the Bolsheviks wanted to remove the teaching of religion from schools. The Vilnius public reacted in an active manner to the information. There were also protests at League events against these intentions by the authorities. For example, the Kapsukas government received from an informant a report that, at a meeting of the League on 2 February, speakers urged the workers to defend religion, 'which the government is assaulting'. 49 Relations between the latter organisation and Muckermann's began to deteriorate. Interference in the daily activities of the League began: logs were not provided to the kitchen, it was forbidden to purchase transport products in the countryside. ${ }^{50}$

The League of Workers at that time realised its idea to have its own newspaper. On 7 February 1919 the first number of the publication Gtos Ludus (People's Voice) came out. An editorial committee of the League of Workers published it. It was planned that it would be a weekly. The editorial committee was based in the premises of the Workers' Committee near St Casimir's Church (Didžioji 92), the administration and the printing press of the newspaper at Karališkoji 7. The number was mostly filled with information from the life of the League, and some international news. In the article 'What do we want' the programme of the League was presented: 'We want to help the poorest among us, we want to have spiritual blessings alongside troubles and work, we want to make our contribution to the good works of culture, and we desire all of this in the name of Jesus. ${ }^{51}$ It was claimed that 'in national affairs there is no greater international than the Church of Christ.' The newspaper invited Catholic workers to struggle against hunger and poverty. In relation to the existing government, the wish was declared to be loyal and 'not to use the economic crisis for political purposes'. The idea was expressed 'why do we not recognise that among the Bolsheviks there are also those who, by their work, honestly and selflessly contribute

\footnotetext{
${ }^{48}$ Waligóra, Walka o Wilno, pp. 123-124.

${ }^{49}$ Ibid., p. 146.

${ }^{50}$ Muckermann, Wspomnienia, p. 11.

${ }^{51}$ Czego chcemy, Głos ludu, 7 II 1919, no. 1, p. 1.
} 
to the happiness of mankind. Their goal is also our goal, although the roads to the common goal can differ.' ${ }^{52}$ In response to the phraseology used by the Bolsheviks, it was said that the fighting was justified only in the case of the restrictions on freedom of religion. The newspaper did not have any sharp comments with respect to the existing government; in general, all the contents were permeated with the spirit of peacefulness and cooperation.

However, we can assume that the appearance of the League's newspaper was the key factor encouraging Soviet repressions against the organisation. The very next day an article appeared in their mouthpiece 'Communist', which argued that organisations developed by the communists could implement much more effectively the programme devised by the League. ${ }^{53}$ According to Boleslaw Waligóra, on the same day the Vilnius revkom banned 'People's Voice' along with other opposition newspapers. ${ }^{54}$ However, in this context, the question of the second issue of the newspaper was not clear: would it reach its readers at all. The editorial article of the first issue states that the next number should come out next Sunday, ${ }^{55}$ on 9 February. In his memoirs, Muckermann states that the reason for closing the newsletter was the article which analysed the differences in prices in the city and the countryside, and indicated that the cause of the higher prices was the profit made by the brokers. According to Muckermann, Jewish speculators, though unnamed, realised that the article was directed against them, and tried to liquidate the newspaper. ${ }^{56}$ There is no such article in the first issue, so it was placed in the second. But if we believe Waligóra, the content of the second number was no longer important for the fate of the newspaper; the Bolsheviks had made their decision after the appearance of the first issue ...

On 9 February a new meeting of the League took place, at which the issue of religious instruction in schools was touched upon again, and there was a firm statement against the Bolshevik plans to eliminate religious instruction. It was promised that a new meeting would be organised the next Sunday, this time in Cathedral Square, from where it was considered to move with the requirements to the

\footnotetext{
52 Ibidem.

${ }^{53}$ Waligóra, Walka o Wilno, p. 146.

${ }^{54}$ Ibid.

${ }^{55}$ Od redakcji, Gtos ludu, 7 II 1919, no. 1, p. 1.

${ }^{56}$ Muckermann, Wspomnienia, p. 12.
} 
premises of the Vilnius Soviet. ${ }^{57}$ The government then decided to take action against Muckermann himself. It believed that the priest was too popular, and that to arrest him seemed quite complicated. By then, the number of League members had reached $10,000 .{ }^{58}$ It was decided first to discredit him, declaring him to be an agent of German imperialism. On 11 February, an appropriate article appeared in 'Communist', and also on the same day (or rather night) the revkom handed the priest a demand that he leave Soviet Lithuanian territory within 24 hours. ${ }^{59}$ Early in the morning, Muckermann went to Bishop Matulaitis to discuss the matter. The meeting was also attended by Julius Ellertas, the parish priest of Sts Johns' Church, in whose area St Casimir's Church was, and the Russian convert princess Gruzinskaite. Muckermann realised that he would have to leave, but planned to go into hiding for some time and complete some unfinished business. It was decided that the League of Workers should continue to operate, Fr M. Pjatrovski was to help it; the board of the League had to take care of the church and the works started, under the supervision of Fr Ellertas. This meant that the administration of St Casimir's, in the absence of Muckermann, was entrusted to Ellertas, and the spiritual care of the League to Pjatrovski. ${ }^{60}$

The moment of choice, when to deal with Muckermann, however, was probably determined more by external causes, than the dynamics of the relationship between the League and the Soviet government. From 30 January to 3 February, new elections to the Soviets in Vilnius were held. By various manipulations of the electoral system, the communists secured a majority in the new Soviet, which, unlike the old one, became an obedient tool in the execution of their will. ${ }^{61}$ After the elections, the activities of other left-wing parties began to be restricted, the communists would accuse of counterrevolution every deputy in the Soviet in the minority opposition if he began to participate actively. Immediately after the election, repressions began against the opposition press, in which, as has already been mentioned, the newspaper of the League of Workers found itself. In addition to this, at that time Przelom and Gazeta Ludowa of the Polish Social

${ }^{57}$ Waligóra, Walka o Wilno, pp. 146-147.

${ }^{58}$ Muckermann, Wspomnienia, p. 10.

${ }^{59}$ Waligóra, Walka o Wilno, p. 147. J. Matulaitis dates this demand as $9 \mathrm{Fe}-$ bruary (Matulaitis, Užrašai, p. 139).

${ }^{60}$ Matulaitis, Užrašai, p. 139.

${ }^{61}$ Waligóra, Walka o Wilno, pp. 130-133. 
Democrats were also closed, as were the Jewish Letzte Najee and the Russian Naš putj. Prior to this, all the parties, even the closest to the Bolsheviks, internationalists and members of Bund, protested against it, but did not gain anything. ${ }^{62}$ So after overcoming the opposition in the political left wing, and taking control of the Vilnius Soviet, the Bolsheviks decided that it was time to take action against Muckermann's organisation. Another not previously mentioned public area in which the Bolsheviks hindered Muckermann's activities was the affairs of workers unions. Just after entering the country, the Bolsheviks set out to revamp the existing trade unions on the new basis of individual activities (e.g. tailors, weavers, metalworkers, etc). That the unions operated on a factory basis did not suit them, i.e. that all the workers in a specific factory or enterprise were gathered in a single unit; it was also undesirable that the unions were formed on a nationality principle. ${ }^{63}$ The matter was very simple: the Bolsheviks were able to introduce their representatives, usually from Russia, into newly created organisations not related to a particular factory or workshop, through which they sought to control all the activities of the trade unions. Although the existing trade unions resisted the changes (the struggle intensified especially at the end of January 1919), the Bolsheviks found an effective way to overcome this: because a subsistence crisis arose and ration cards were introduced for the population, they were issued only to workers who joined the new trade unions. ${ }^{64}$ Meanwhile, the emerging League of Workers was working just in the opposite direction to the whims of the Bolsheviks. Immediately craftsmen began to register, seeking to establish joint workshops, unionised under the banner of the League, tailors and shoemakers established cooperatives; finally, the League, with many sections, in many cases acted as a strong union of workers.

After the deliberation with Bishop Matulaitis, the very same day the episode of Muckermann's arrest and the defence of St Casimir's Church began leaving the most vivid impression on contemporaries of the League's activities. It is described in detail in the memoirs and the historiography mentioning the activities of Muckermann, and in our study we will recall it only in general terms. ${ }^{65}$ On that date

62 Ibid., pp. 133-134.

${ }^{63}$ Ibid., pp. $115-118$.

${ }^{64}$ Ibid., p. 119.

${ }^{65}$ For the most complete account see: Matulaitis, Užrašai, pp. 139-142; Muckermann, Wspomnienia, pp. 14-19. 
the news spread immediately that Muckermann was being deported, and the Catholics were stirred up. They began to assemble in St Casimir's Church. When the popular Jesuit appeared, wanting to say goodbye to the people, the crowd would not let him leave. A crowd also began to assemble around the church. The Soviet militsia undertook to 'restore order', they fired shots into the air, but also hit the church. After that, the crowd became enraged, and disarmed the militsia. The conflict spread, the government surrounded the church with reliable Red Army soldiers, who let people leave, but did not allow anyone to enter. Those trapped in the church, meanwhile, prayed, stood watch, and protected Muckermann. However, on the third day of the siege, when the people were very tired and starving, armed Bolsheviks entered the church by force, arrested and took out the priest, and the large crowd that had been with him. During this invasion, some were also beaten and injured. Bishop Matulaitis during those days did everything he could to save the leader of the League. Initially, through Fr Juozas V. Kukta, he sent to Kapsukas the latter's old acquaintance and benefactor Emilija Vileišiene to persuade him not to touch the German priest. ${ }^{66}$ Since this did not help, he sent Fr Juozas Tumas to Kapsukas with his own written letter interceding for Muckermann. In this letter, the bishop stated directly that the priest acted with his knowledge and as his authorised representative, but had not committed any crime and did not pursue any politics. Kapsukas replied to Tumas that they could not let Muckermann remain in Vilnius, and would keep the church under siege until the people surrendered. But he promised that nothing wrong would be done either to the people or the priest. ${ }^{67}$ Kapsukas did not fulfil his promise ...

The government locked up and placed a guard on St Casimir's Church and the adjacent premises of the League, and a perquisition of the premises was carried out, during which some items disappeared. The bishop again sent Tumas back to Kapsukas, with a written request to return the keys and to allow people to pray in the church, as well as to release the detainees. The leader of the Bolshevik government promised to agree with everything, but refused to release the German priest. Later, Kapsukas even sent a letter to the bishop, announcing that Muckermann had been taken to a prison in Minsk, where he would be tried; with this letter, the government wanted to deny the

\footnotetext{
${ }^{66}$ Matulaitis, Užrašai, p. 140.

${ }^{67}$ Ibid., pp. 140-141.
} 
rumours that the priest had been killed, and asked the bishop to calm down the believers. ${ }^{68}$ The calm and encouraging stance of Bishop Matulaitis during these days seems to have helped the League to put itself in order and begin to reorganise its activities under different conditions. He advised the members of the League's board, who were frightened by the arrest of Muckermann, not to run away from Vilnius, but only to avoid arrest by not spending the night at home until the situation became clearer. He advised Fr Pjatrovski to organise a board meeting to discuss the situation; the board subsequently met at the home of Fr Ellertas. ${ }^{69}$ It soon became apparent, however, that the Bolsheviks had not plundered the League's cash, which was very important for the continuation of its activities. The most important immediate task became obtaining the release of those arrested. Representatives of the League who were authorised to speak with the government consulted with the bishop and asked for his support and advice. For the next Sunday, the bishop prepared a statement which was read out in all the churches in Vilnius. Matulaitis noted that it was difficult to prepare such a text. ${ }^{70}$ On one hand, one needed to soothe and encourage the workers and the entire Catholic community, on the other hand to avoid sharp comments with regard to the government. Moreover, the bishop decided to give the Sunday sermon at St Casimir's Church, and because the church was still locked, he spoke in the Cathedral, which on this occasion was overflowing. He mentioned the arrest of Muckermann, urged people not to become discouraged, and to continue the work begun which he himself would always support. ${ }^{71} \mathrm{He}$ called for a meeting after Mass in the former premises of the League. This meeting actually took place, and it was again decided to send delegates to the government. The next day, the League's envoys, repeatedly encouraged by Matulaitis, obtained an appointment with Pranas Eidukevičius, the representative of the government. He also promised to return the church and release the arrested; moreover, he suggested that the bishop appoint some priest to St Casimir's Church, and sent representatives to take it over. ${ }^{72}$ As had already been agreed under Muckermann, Fr Ellertas became the

\footnotetext{
${ }^{68}$ Ibid., pp. 141-142.

${ }^{69}$ Ibid., p. 142.

70 Ibid., p. 143.

${ }^{71}$ Ibid., pp. 146-147.

${ }^{72}$ Ibid., p. 148.
} 
parish priest and Fr Pjatrovski and Fr Juzef Chrucki, a refugee from the Mogilev diocese, were charged with saying Mass in the church. ${ }^{73}$

So St Casimir's Church was returned to the faithful, and little by little the arrested were also released. On 20 February, a nun arriving from Minsk in the name of the bishop there Zygmunt Lozinski announced that the Rev Muckermann was in a Minsk prison, they had been planning to shoot him, but then decided to organise a trial; the workers themselves should defend him. Informed about this, the board of the League decided to send representatives to Minsk to clarify the situation. ${ }^{74}$ On 27 February, after a meeting between the bishop and a representative of the workers travelling to Minsk, it was decided that the League of Workers would send representatives to the trial, and the bishop would send a priest. ${ }^{75}$ This was the Belarusian Andrzej Cikoto. The latter wrote to Matulaitis on 10 March that for four days in Minsk he and the representatives of the workers had walked around government offices seeing to the matter of Muckermann. ${ }^{76}$ The Bolsheviks had classified the Muckermann case, so it required a lot of effort to learn anything. He wrote that the arrival of the workers' delegation and their request with signatures made a great impression on the chairman of the interrogation commission and other employees. Cikoto advised the bishop to send a second official delegation to defend Muckermann. ${ }^{77}$ Soon, however, the Bolsheviks transported the German priest to prison in Smolensk prison ...

The activities of the League of Workers were limited by the Bolshevik government and denied publicity, but they did not stop, they just took on other forms. It is not difficult to understand the approach of members and sympathisers of the whole Catholic community to the Bolsheviks after the story of Muckermann's arrest. The Lithuanian Christian Democrat newspaper Tiesos kardas (Sword of Truth) wrote very perceptively: 'Probably the Military Revolutionary Committee believes that after seizing the leader of the League it would enslave for itself those 12,000 workers, but the big question is whether Kapsukas' government will benefit from the persecution of workers'

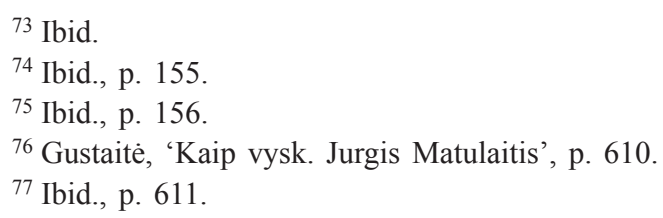


organisations.' 78 In the spring, the position of the Bolsheviks on the Western Front became critical. On 19 April, Poles, who after several days of fighting established themselves in the city, drew imperceptibly closer and invaded Vilnius. A new phase of existence began for the League of Workers.

Members of the League actively helped the Polish army in its battles with the Bolsheviks for the city. As the officer Tadeusz Piskor wrote, 'several hundred workers from the St Casimir Society were armed.' 79 Some of them paticipated in active combat, others stood guard, still others served as army guides in the city and its vicinity. Lithuanian sources also mention the active assistance by members of the League given to Polish soldiers. ${ }^{80}$

After the Polish government was established, the activities of the League came out into the open again. On 27 April, representatives of the organisation spoke at the rally in Lukiškès Square, where about 5,000 people assembled. Among other things, they demanded 'to organise the national economic life of the country reviving the industrial and commercial relationship, so that our production and trade do not fall into foreign hands'. ${ }^{81}$ Here, first of all, they had in mind the Jews. On the same day, the League organised its own meeting. On 3 May, representatives of the organisation participated in the rally commemorating the Constitution of the Polish-Lithuanian Commonwealth. On 4 May, it proclaimed a resolution which accused the Jews of disloyalty to their fellow Poles in the periods of German and Bolshevik rule. ${ }^{82}$ The League began to emphasise its existence through active participation in the social life of the city. For example, on 6 July it contributed to the solemn commemoration of the Union of Lublin.

After the military operations quietened down, in July the Jesuit provincial sent his representative Fr Ludwik Rudnicki to Vilnius, and then Bishop Matulaitis formally, with a document, entrusted St Casimir's Church to the Jesuits. ${ }^{83}$ The priest also became a member

${ }^{78}$ Katalikų darbininkų lyga, Tiesos kardas, 21 February 1919, no. 39, p. 2.

${ }^{79}$ T. Piskor, Wyprawa wileńska (Warsaw, 1919), p. 34.

${ }^{80}$ Report of M. Biržiška of 3 July 1919 at the meeting of the Lithuanian Cabinet of Ministers, LCVA, f. 923, ap. 1, b. 24, 1. 44.

${ }^{81}$ Wiec ludowy, Dziennik Wileński, 29 IV 1919, no. 9, p. 1.

${ }^{82}$ Rezolucja wiecu Ligi Robotniczej św Kazimierza, Dziennik Wileński, $6 \mathrm{~V}$ 1919, no 14, p. 1.

${ }^{83}$ Gimnazjum Ojców Jezuitów, pp. 38, 50. 
of the League's board, and this was only one part of the gradual but biased change in the chain of management. Muckermann's fellow Jesuit M. Malik, during a Bolshevik campaign in February, was also arrested, even though he was sick. He ended up in Poland, and did not return to Vilnius. ${ }^{84}$ After a while, Pjatrovski was appointed parish priest of Baruny. So the leadership of the League fell into the hands of the Poles, who again returned to militant nationalism. After the expulsion of the Bolsheviks at the end of April 1919, the Board of the League comprised S. Górski (chairman), B. Nejman, and J. Łokuciewski (secretary). ${ }^{85}$ Accordingly, the posture and rhetoric of the organisation founded by Muckermann also changed. The Vilnius Lithuanian publication Aušra (Dawn), begun in July 1919, wrote in its first issue: 'As long as Fr Muckermann was there, the workers obeyed him and did not like to interfere in politics. Everything has changed now. No Polish national celebration or demonstration can do without this workers' organisation. We have not yet heard that the St Casimir League of Workers would ever have participated in a Lithuanian or Belarusian celebration, even though on its flag, together with the eagle, it has emblems of Lithuania and Belarus. The workers, of course, listen to their leaders today, in the midst of whom several endeks, who care more about the Polish identity than the Catholic faith, have intruded. ${ }^{86}$

On 5 October 1919, the third issue of 'People's Voice' appeared. The motto under the newspaper's title: 'With God and the Nation' ( $Z$ Bogiem i Narodem!) (in the first issue it had been 'With God and the People' ( $Z$ Bogiem i Liudem!)) testified to the changed rhetoric. Although the issue extolled the merits of Muckermann, promised to continue his begun works, and wrote widely about how institutions of the League worked and developed, most of the content was imbued with the interests of the Poles and Poland. Even more: the Lithuanian 'council members', next to the Russians and Germans, were directly called enemies. ${ }^{87}$ In the foreign news section, reporting about the fights between Poles and Lithuanians on the border, Lithuanians were described using the epithets 'ignorant', 'dark', 'poor', the Lithuanian

${ }^{84}$ Ibid., p. 37.

${ }^{85}$ Narkowicz, Jan Konrad Obst, p. 201. At that time, the number of League members reached 15,000 .

${ }^{86}$ Darbininkų lyga, Aušra, 13 July 1919, no. 1, p. 12.

${ }^{87}$ Czego nam trzeba, Głos ludu, 5 X 1919, no. 3, p. 1. 
leaders were 'bribed by the Germans', and so on. ${ }^{88} \mathrm{~S}$. Gorski was the editor and publisher of the newspaper.

During this period, an important task of the League became aiding wounded Polish soldiers at the front, so offerings were collected, which were transferred to the hospitals in Vilnius. ${ }^{89}$ In the unstable economic period, attention was also paid to the subsistence of the townspeople, and therefore the government was assisted with purchases of food products (flour, bacon, potatoes), footwear and so on. Of course, participation in public life was not forgotten, for example, at the opening ceremonies of Stefan Batory University. ${ }^{90}$

In August 1920, under the Lithuanian government, representatives of the League belonged to the newly created Polish Committee, which had to represent and defend the interests of Polish society in the Vilnius region. Some time later, after the action of General L. Želigowski, the committee worked closely with the 'Central Lithuania' administration being created. ${ }^{91}$ In 1921, Fr I. Olszański (the same who had been dissatisfied with the activities initiated by Muckermann!) stood at the forefront of the League, and in 1922 the leadership shifted to the known Polish endek, journalist and editor Jan Obst. ${ }^{92}$ The priests Karol Lubianiec and Jozef Songin, criticised by Bishop Matulaitis for Polish chauvinism and intolerance, became involved in the activities of the League. In the period 1922-1925, the press reported on the active participation of the League in the public life of Vilnius, ${ }^{93}$ but the involvement acquired more and more features of theatricality and window-dressing; great attention was paid to marches in the streets and playing music. Obst tried to present himself as a lecturer and educator in the halls of the city. One gets the impression that the further it went, the League became more and more an anachronism in the life of a Polish city; the tasks for which it was established had been taken over by purely Polish-origin organisations already in the course of 1919, and the dissolution of the League then would have been natural. However, for the residents of Vilnius, the League had become a symbol of resistance to Bolshevism. The legend of

${ }^{88}$ Co słychać nowego w Polsce i za granicą, ibid., p. 4.

${ }^{89}$ Dawajcie na rannych, ibid., p. 3.

${ }^{90}$ Udzial Ligi Robotniczej w uroczystościach otwarcia Uniwersytetu, ibid., pp. 2-3.

${ }^{91}$ Dąbrowski, Rozpolitykowane miasto, pp. 59-60.

${ }^{92}$ Narkowicz, Jan Konrad Obst, p. 205.

${ }^{93}$ Eadem, pp. 435-436. 
Muckermann was still alive, and for the government it was helpful to continue to operate as a sign, before that, of course, trying to make all of the content Polish. But time was moving on, the topical issues and challenges of the period changed. In 1927-1928, the press still reported that the League was organising entertainment, dances for youth, and children's entertainment, during which chocolate and sweet rolls and so on were offered. ${ }^{94}$ However, after 1929 we do not see reports in the press even about these activities. From this, the Polish scholar L. Narkowicz assumes that if the organisation continued to exist, it did so only fictitiously. ${ }^{95}$

So, as we can see, through the entire existence of the League, we can distinguish at least several phases of its activities. First, when the organisation was founded and led by Fr Muckermann. The second lasted from Muckermann's arrest until the entry of the Polish army into Vilnius in April 1919. After that began the third, the longest stage in its existence, under the Polish government. It is obvious that during all these stages, the League was not uniform in its characteristics. Current Polish investigators somehow are reluctant to notice this. For example, Narkowicz quite rightly points out that 'in the period of the recovery of independence, one of the key objectives of the League was the encouragement of the spirit of citizenship among its members, so that they understand what they can expect from the state and what they can give to it for the cause of good and successful development. ${ }^{96}$ But already in the next paragraph of her work, the researcher, without any reservations or comments, just bluntly states that the League 'sought the unconditional union of Vilnius and the Vilnius region into Poland'. Reading such a text, it remains unclear the citizenship of which state, Lithuania or Poland, the League sought to develop. From the whole context, it would appear to be Poland's. But if this applied to the period of Muckermann's leadership, it is clearly false. Or we need to emphasise that it is about the period from the end of April 1919.

As we can see, there are quite a few other Lithuanian issues in the history of the League of Workers that Polish researchers tend not to deal with, and this is especially true about the period of Muckermann's leadership. The role of Bishop Matulaitis is most important here. Nevertheless, the bishop, as all his biographers agree, was first

\footnotetext{
${ }^{94}$ Ibid., p. 436.

${ }^{95}$ Ibid.

${ }^{96}$ Ibid., p. 435.
} 
of all an impartial shepherd of Catholics of all nationalities, and only then a Lithuanian. We, meanwhile, are interested in the relationship between Muckermann and his organisation and the politically motivated Lithuanian activists, and through them perhaps with the emerging government of Lithuania. Surely there were some business contacts in December 1918, when the Lithuanian government was still in Vilnius and the beginnings of the League of Workers also appeared. Mykolas Biržiška, the minister of education, and the future leader of the Vilnius Lithuanian community, then determined the issue of the transfer of buildings freed from the German government to Muckermann's people. ${ }^{97} \mathrm{We}$ do not have information about the details of the contacts begun at that time, but the initial contacts had undoubtedly developed into discussions on wider topics. According to Biržiška, Muckermann said that he did not sympathise with the Polish-led policies. ${ }^{98}$ Also, according to this Lithuanian activist, the work of Muckermann went on with his knowledge and consent, ${ }^{99}$ and, of course, as an alternative in the context of Polish actions. Without knowing the details, one can argue and doubt the precision and consistency of the contacts mentioned, but one thing is certainly true: the direction vectors of Lithuanian politicians and Muckermann's organisation in that period coincided. This is quite simple, the overall scheme of the situation was such: the Lithuanians were desperately seeking to establish a political foothold in Vilnius, where, however, they comprised as a percentage a paltry minority of the population; one possible solution was to somehow consolidate around themselves as many as possible of the non-Lithuanians; Belarusians and Jews seemed to gravitate towards the consolidation; but the Poles, the most numerous and the most influential Vilnius residents, held steadfast, and moreover, they themselves aimed to absorb politically all the remaining non-Polish society. And here, after the Bolsheviks arrived and suppressed the claims of the Poles, totally unexpectedly (more precisely, thanks to Muckermann), consolidation began on a religious-cultural basis. For Lithuanians, this should have been important, and at the same time favourable, because, first, they were brought into the new consolidation without having to give up anything in its favour, and second, this religious-cultural consolidation had

${ }^{97}$ Biržiška, 'Dèl mūsų sostinès', pp. 69-70.

${ }^{98}$ Report of M. Biržiška at the 3 June 1919 meeting of the Lithuanian Cabinet of Ministers, LCVA, f. 923, ap. 1, b. 24, 1. 44.

${ }^{99}$ Ibid. 
the potential under the right circumstances to grow into a political consolidation favourable to Lithuanians. After all, what Muckermann did was essentially, as it later appeared, quite a successful attempt to mobilise the population of historical Lithuania on the basis of values. After all, remembering the plans of the government of Augustinas Voldemaras for the creation of a Lithuanian state in the borders of the Oberost, ${ }^{100}$ as well as the fact that the first government of Mykolas Sleževičius did not have any firm stance on where in the east it should end, ${ }^{101}$ we can state with justification that in the plans of Lithuanian politicians at that time, there was still room for a modified, reduced historical Lithuania.

Taking a retrospective look at the situation in Vilnius at the turn of 1918-1919, we can see that the Christian social activities inspired by Bishop Matulaitis and the activities of the organisation of Muckermann evolving from it, brought into the public eye several personalities promising to be a real alternative to the entrenched Polish activists. Each of them worked at a particular moment, and had a distinctive touch, but was favourable to the positions of Lithuanian statehood. The principal provisions of Bishop Matulaitis gave rise to the whole process; with the way circumstances turned out in Vilnius, there appeared the ethnically neutral, F. Muckermann with ideas congenial to the bishop; at the same time with extraordinary abilities the equivalence of the Belarusian policy conducted by the bishop produced the Rev M. Pjatrovski, who came to assist Muckermann, and later the Belarusian Fr A. Cikoto joined in. The operation of these personalities created, we can say today, a surprisingly favourable background for Lithuanian plans with respect to Vilnius. It seems that in the spring of 1919, a quite realistic scenario whereby these several hundred armed members of the League helped not a Polish but a Lithuanian army advancing on Vilnius could have been realised... One can claim that the Bolsheviks, by removing Muckermann, also at the same time indirectly dealt a painful blow to the chances for the Lithuanians to return to Vilnius. But we should also observe that the arrest of Muckermann determined the

${ }^{100}$ For more information see: E. Gimžauskas, 'Kai kurios 1918 m. lapkričio 27 d. lietuvių ir gudų politinio susitarimo aplinkybės (Lietuvių ir gudų santykių raida 1917-1918 m.)', Lituanistica, 1999, No. 4, pp. 3-31.

${ }^{101}$ Only the second government of M. Šleževičius undertook the detalisation of the country's borders in April 1919 (protocol of the 13041919 meeting of the Lithuanian Cabinet of Ministers, LCVA, f. 923, ap. 1, b. 24, 1. 127-130). 
conversion of the League from a peaceful non-political organisation to a gathering of strictly opposition-minded individuals, also not rejecting the option of an armed struggle against Bolshevism. With the Poles successfully exploiting this conversion in their favour, it was not clear that the Lithuanians were at least trying to compete with them in this direction (primarily through Belarusian priests). The reason was probably because the Lithuanians clearly lacked a competitive potential in church spheres: the further development and orientation of the League were mainly determined in them.

Returning to the citizenship question in the functioning of Muckermann and his organisation, we should stress that the League essentially carried out a cultural consolidation, the mobilisation of the population of the capital of a historic state on the basis of Catholic values. In Western societies, due to the overlap of historical, political and cultural boundaries, it is normal and unquestionable that there exists the civil resolve of individuals of one and the same culture to live in one state. Such a culture quite reasonably could exist, and was identified with the legacy of a state destroyed by violence, which, in turn, still alive in the minds of the people, formed the legal basis to restore this state. In this way, the model of historical statehood is closely linked to the principle of civic nationhood. However, in the case of Lithuania, the great conflict for historical statehood was in the relationship between the GDL and the Polish-Lithuanian Commonwealth. Having entered the era of modernism, the nations of Central and Eastern Europe sought their own countries on a national basis; but, however, in their mutual disputes in the presence of arbitrators of the West, generally resorted to the argument of historical statehood. The unrivalled leaders here were the Poles, who also had the most extensive space for manipulation, which was particularly sensitive in the Polish-speaking Vilnius region. In short, when the issue of historical statehood arose, Lithuanians and Belarusians always stood up for the GDL (in fact, with different borders envisioned), and the Poles for the Commonwealth. In Poland, due to its specific social structure, influenced by the legacy of the pre-modern era, there were strong forces, which, it seems, truly, and not for purposes of shelter, sought the restoration of the historical Commonwealth. They made up a powerful current of federalists, at the forefront of which stood the charismatic J. Pilsudski. Anyhow, the goal of the Polish nationalists (endeks) and the federalists was one: the formation of a 'Great Poland', with its maximum 1772 borders. Nevertheless, in 
the agenda of the supporters of Pilsudski, a homogenous Poland did not figure, but separate with it a federated Lithuania, Belarus and Ukraine, as a kind of compromise between the national and historical principles and the guarantee for civil peace in the huge state. All of this had the basis under the relevant conditions (which were made by purposefully interpreting the entrance of the Polish army into Vilnius in April 1919) to seem tempting enough to the non-Poles of the Vilnius region, primarily the supporters of civil consolidation, and probably more seductive than the policy of the Kaunas-based Lithuanian government with respect to the Vilnius region. Anyhow, the proponents of civil consolidation in Muckermann's organisation saw a future for the implementation of their regulations in collaboration with the supporters of Pilsudski. The case of the mentioned Belarusian priest Pjatrovski testifies to this. In February 1921, Bishop Matulaitis, in a conversation with General Stefan Mokrzecki, the chairman of the Interim Control Commission of Central Lithuania, defended the priest from the last attacks of the latter. ${ }^{102}$ This conversation shows that when Fr Pjatrovski, working in Baruny, on one hand continued active Belarusian cultural activities, and on the other became actively involved in the party structure of the Polish People's 'Odrodzenie'. The endeks, whom General Mokrzecki also represented, did not like this. They demanded that Pjatrovski be removed from Baruny. Bishop Matulaitis countered them by pointing out that Pjatrovski worked with the knowledge of Mokrzecki's predecessor Witold Abramowicz (a supporter of Pilsudski), having worked together with the Polish Christian Democrats; and, moreover, he had not in any way violated church law, so he could not punish him. ${ }^{103}$ The bishop recalled that Fr Pjatrovski, with the League of Workers, helped capture Vilnius, and for this he had received praise from the Polish government. At that time in the conversation, the elderly supporter of the endeks Archbishop Karol Hryniewiecki said that at that time the priest was good, but had now strayed from the true path (!). ${ }^{104}$ This conversation not only provided information about Pjatrovski's further career after cooperation with Muckermann. It also highlights the further turns in the cooperation between Muckermann's associates and the Polish administration, and more precisely, reveals the fiasco of the attempt to cooperate with the Polish federalists. Initially, promising great

102 Matulaitis, Užrašai, pp. 237-246.

${ }^{103}$ Ibid., pp. 238-239, 242.

${ }^{104}$ Ibid., p. 239. 
hopes (even the Lithuanians in Vilnius were seriously interested in it $^{105}$ ), the policy of the federalists gradually weakened, and the line represented by the endeks in its administration policy became ever more more evident.

Meanwhile, the fate of Muckermann in Bolshevik captivity, although implicitly, was again influenced by events in Vilnius, having quite unexpectedly become an important factor in Soviet foreign policy. Ten days after the invasion of Vilnius by the Polish legionaires, the Bolshevik authorities in Moscow arrested 250 Polish 'bourgeois' representatives as hostages, among whom was the former Bishop of Vilnius Edward Ropp. ${ }^{106}$ As was announced, this was a reaction to the Polish actions in Vilnius, for the suddenly invading Poles (as is known, also with the help of the League of Workers) attacked and captured not only Red Army troops but also a number of Bolshevik activists. Seeking to rescue them, Moscow officials also organised a hostage campaign. Already in July 1919, after Soviet and Polish contacts for the exchange of hostages were developed, introductory talks were held in Bialowieza on this question. In the autumn, an attempt to conclude a possible peace began: because Pilsudski saw the lack of friendliness by the White Russians towards Poland, he refused to contribute to the attack of Denikin in the direction of Belarus, and decided to see the Soviets as a partner for negotiations. On this basis, talks between Russians and Poles began in October in Mikashevichy. (The softening of Bolshevik-Polish relations most likely also affected the approach to Muckermann: he was permitted to reside in Smolensk outside the prison and look for a source of living.) Parallel serious discussions began between the main Soviet negotiator Julian Marchlewsky and the Polish representative Michał Kossakowski on the subject of hostages. At these meetings, the issue of the release of Muckermann was mentioned. Kossakowski wrote that he had received from Vilnius a petition with 5,500 signatures of members of the League of Workers, in which the Polish government was asked to make efforts towards Muckermann's liberation. ${ }^{107}$

${ }^{105}$ For more information see: Č. Laurinavičius, 'Dèl lietuvių ir lenkų susitarimo galimybių 1919 m. balandžio - birželio mènesiais', Politika ir diplomatija. Lietuviu tautinès valstybès tapsmo ir raidos fragmentai (Kaunas, 1997), pp. 66-79.

${ }^{106}$ Z. Ponarski, 'Za kulisami wielkiej polityki', Zeszyty Historyczne, no. 131 (Paris, 2000), p. 204.

${ }^{107}$ Ibid., p. 210. 
On instructions from the Kremlin, Marchlewsky linked the release of both Muckermann and Ropp with the release of the famous Bolshevik Karl Radek from a prison in Germany, and his transfer through Polish territory to Russia. Radek had been appointed as a Soviet delegate to the peace negotiations with Estonia, and Germany agreed to release him on condition that Poland allowed him to cross into Russia. (Radek had been arrested in Germany on 12 February 1919, at the same time as Muckermann in Vilnius, and this was a basis for the assumption that the order for the actions against Muckermann had come from Moscow, as a countermeasure to the operations of the German service). On 2 November, a treaty for the liquidation of the system of hostages, opening the way to freedom for all the arrested Poles, was signed. However, the negotiations for Ropp and Muckermann continued, because the Kremlin linked their question directly to the issue of Radek. ${ }^{108}$ The Council of People's Commissars asked for the early release of Radek, and only on 10 November was Marchlewsky, returning to Moscow after a break in negotiations, given freedom of judgment. On the other hand, Pilsudski himself personally became involved in the solution of the issue. On 21 November, Marchlewsky returned to Mikashevichy, bringing with him Bishop Ropp, and on the way also taking from Smolensk Muckermann and the Pole Maria Kossakowska. The case of Ropp was special, in that the papal curia itself was concerned about him as the shepherd of Russia's faithful, and although Muckermann was a German, the Polish negotiators presented him 'as a permanent resident of Vilnius'. ${ }^{109}$ In negotiations in Mikashevichy, it was also decided how to organise Radek's 'transit'. Here again, the peculiarity of Muckermann's personality was expressed. The latter, having survived the brutal Bolshevik prison conditions, did not feel at all like a prisoner. The Bolsheviks were especially surprised by the desire of Muckermann (like Bishop Ropp) to return to Soviet Russia in the future. The German priest criticised 'Polish militarism' in the negotiations, perfectly in harmony with the Soviet negotiators. ${ }^{110}$ Several alternatives were considered for Radek: a letter

${ }^{108}$ Ibid., pp. 207-209.

109 J. Marchlewski w rokowaniach polsko-radzieckich w październiku - grudniu 1919 r., Archiwum Ruchu Robotniczego 4 (1977), p. 176.

${ }^{110}$ J. Marchlewski wrote about this on 26 November 1919 from Mikashevichy to L. Karachan in Moscow (Dokumenty i materialy do historii stosunków polsko radzieckich, t. 2, red. N. Gąsiorowska-Grabowska (Warsaw, 1961), pp. 445-446.). 
from Marchlewsky to his 'lawyer' in Berlin, a letter from Bishop Ropp to the vice-chancellor and famous German Catholic activist Matthias Erzberger, as well as the personal initiative of Muckermann in Berlin. ${ }^{111}$ The latter option was chosen!

Muckermann met with Pilsudski in Warsaw, and agreed with him that he would seek Radek's release in Berlin. It was important for the Poles that the initiative for the liberation of this Bolshevik activist would come not from their side. Later, Radek wrote that 'from a Jesuit monk freed from prison together with Bishop Ropp of Vilnius', he learned that between Pilsudski and 'us' a secret agreement was made under which Poland promised that it would give him transit. But the Germans did not believe this until the appropriate telegram from Warsaw had arrived. ${ }^{112}$

After the successful liberation of Radek, Muckermann did not return to Soviet Russia, or to Polish-ruled Vilnius. He found a broad area of activity in Germany itself. First of all, he completed his interrupted theological studies, and dedicated himself to the work of the Catholic press. Through his efforts, a comprehensive, multi-sectoral Catholic news service was created. ${ }^{113} \mathrm{He}$ published the cultural journal Der Gral (The Grail) himself until 1931, through which he sought to promote and popularise the world-view values he represented. ${ }^{114}$ He cooperated actively with the longstanding Catholic publication Stimmen der Zeit (Voices of Time). In addition to his tireless activities as a publicist, Muckermann was a Jesuit with wide interests whose life's purpose became the synthesis of the Christian faith and modern humanity and its culture. ${ }^{115} \mathrm{He}$ belonged to social-intellectual societies of Dante, Fichte, Görres, and German writings. He became known as a preacher, and gradually became one of the most prominent activists of the Weimar German Catholic movement. Among his literary works perhaps the most significant is the interpretation of Goethe's works (Goethe), appearing in 1931, in which he finds and highlights Christian motifs in the work of

${ }^{111}$ Ponarski, 'Za kulisami wielkiej polityki', pp. 210-211.

112 Ibid., p. 211.

${ }^{113}$ C. Vollnhals, 'Muckermann Friedrich', Biographisches Lexikon zur Weimarer Republik, hrgs. von W. Benz und H. Graml (Munich, 1988), p. 232.

${ }^{114}$ Muckermann Friedrich, Deutsche Biographische Encyklopädie, ed. W. Killy, Vierhaus, vol. 7 (Munich, 1999), p. 238.

${ }^{115}$ Vollnhals, 'Muckermann Friedrich', p. 232. 
this famous writer, contrary to the entrenched image in the Catholic environment of Goethe as 'an old pagan'. 116

After the episode of his work in Vilnius and his stay in Bolshevik captivity, Muckermann became famous as an implacable opponent of Bolshevism. After returning from imprisonment, on the basis of his experiences, he published in Germany the brochure Wollt ihr das auch? Wie ich den Bolschewismus in Rußland erlebte (Do You also Want to? How I Survived Bolshevism in Russia). ${ }^{117}$ After the Nazi movement began to strengthen in Germany, the priest also began to criticise the heightening negative traits of the latter in the same way, especially the promotion of neo-paganism. As a result, after coming to power, the Nazis declared Muckermann an enemy of the state. In July 1934, with the help of his brother, also a priest, he escaped imminent arrest by fleeing to Holland. There he began to issue the publication Der deutsche Weg (The German Way), for German-speaking Catholics in the Netherlands, but which was also illegally distributed in Germany. Because of his activity, however, he was forced to leave the Netherlands in 1936 and stay in Rome, where he worked at the Vatican's Oriental Institute. There, he also began to run a Jesuit newspaper with an anti-Bolshevik stance Lettres de Rome, in which he also fought against Nazi ideology. Anticipating a threatened crackdown, at the end of 1937 he moved to Austria, where the regime still tolerated anti-Nazi sermons. There, the priest belonged to the circle of advisers of the Austrian Chancellor Kurt von Schuschnigg. Nevertheless, the Gestapo followed in the footsteps of Muckermann everywhere in Europe. After the Anschluss of Austria, the priest was forced to flee to France. From November 1939 to July 1940, he worked at Paris radio as a German broadcast commentator. After the German army occupied France, he fled to the interior, and later hid. In 1943, he fled to Switzerland, where he remained until the end of his life in 1946, still active in publicist activities. ${ }^{118}$

116 Ibid.

${ }^{117}$ In 1922 the leader of the League of Workers J. Obst translated the brochure from German into Polish and then published it in Vilnius. We used the translation (F. Muckermann, Wspomnienia z niewoli bolszewickiej) in this study. However, we have to say that it was 'adapted' for the Polish reader, which is also stated in the introduction to the translation.

${ }^{118}$ For more information about the activities in emigration see: Biographisches Handbuch der deutschsprachigen Emigration nach 1933, p. 510; Gruber, 'Muckermann Friedrich', pp. 274-276. 
Even though he fought actively with the National Socialist regime, Muckermann was not one of its radical opponents. For example, his published 'German Way' had a national-conservative direction, directed at the authoritarian regime in Austria. He did not categorically rule out the fascist form of statehood, but he strongly criticised Nazism for its assumed role of a new religion and its interference in the work of the Church. ${ }^{119}$ During the period of the Weimar Republic, the priest considered as politically the most acceptable the idea of a conservative-caste Catholic state. In Eastern Europe, in the fusion of Western and Russian culture, he saw the centre of the new world of the future. ${ }^{120}$ Some of his biographers, such as Clemens Vollnhals, were inclined to note that for Muckermann, democracy, like Anglo-Saxon culture, remained intrinsically foreign. ${ }^{121}$ After the Second World War, he opposed the thesis that all Germans should assume collective moral guilt for the consequences of Nazism. Nevertheless, his unquestionable merits in the fight against the greatest totalitarian systems of the 20th century are generally recognised. In an annotation to the memoir about Muckermann Im Kampf zwischen zwei Epochen (In the Struggle between Two Eras), released in 1973, it is written: 'Muckermann fought persistently against left and right radicalism, against Bolshevism and National Socialism. As was announced on Nazi posters, Hitler's regime considered him as public enemy No. 1. The Gestapo chased him over half of Europe, unable to break his fighting spirit.' ${ }^{122}$ One of his main biographers, the German historian Hubert Gruber, said about him: 'Friedrich Muckermann was a man who, without doubt, in the era of the Weimar Republic, was one of the most prominent German Catholic literary critics, publicists and speakers.' ${ }^{123}$

119 Biographisches Handbuch der deutschsprachigen Emigration nach 1933, p. 510 .

${ }^{120}$ Vollnhals, 'Muckermann Friedrich', p. 232.

${ }^{121}$ Ibid.

${ }^{122}$ Boruta, 'Palaimintasis Jurgis Matulaitis', p. 335.

${ }^{123}$ Gruber, 'Muckermann Friedrich', p. 266. 


\section{Conclusions}

Having gained momentum at the end of the 19th century, the transformation of Catholicism from a confessional to a public category created the conditions for founding the Vilnius League of Workers. This organisation, on one hand, was one of the many community organisations in the context of Christian social actions. But usually at the beginning of the 20th century such organisations were formed on a national basis. So the very fact that the League of Workers was founded in the multicultural environment of Vilnius, in addition, against the background of huge political upheavals conditioned by the First World War, partly determined its uniqueness.

We can consider with justification the appearance of the League of Workers in Vilnius a case when the subjective factor essentially influences and determines the social process. Due to the personal qualities and efforts of Fr Friedrich Muckermann, the idea of the organisation began to be realised in Vilnius. We can also record in the contents of the subjective factor the simultaneous circumstance that at that very time a specialist in Christian social activity, Fr Jurgis Matulaitis, became Bishop of Vilnius, and took care of Muckermann.

To the objective factors, we should attribute the fact that the undertaking of Muckermann found a lively need in the Vilnius environment. The arrival of the Bolsheviks, on one hand, accentuated and distorted the social question. On the other hand, the Bolshevik government suppressed the trend in the alignment of Catholicism with the Polish identity, so assumptions of the consolidation of Catholics of different nationalities began to emerge on the basis of Christian values.

The consolidation of Catholics begun by Muckermann was also the consolidation of a significant part of the society of the former capital of the GDL. The fact that this consolidation began successfully, naturally attracted the attention of the elites of the different nationalities based in Vilnius, whose own broader efforts at consolidation had not been successful. Because the consolidation begun by the Jesuit priest on a cultural basis under the appropriate conditions had the potential to grow into a political consolidation of the basis of the historical statehood of the GDL, this, in turn, involved the plans of political activists of different nationalities. Because the realisation of historical statehood in the 20th century is imagined only as civil 
self-determination, we can view the activities of Muckermann and his comrades as a social shift towards citizenship.

The Vilnius clergy influenced crucially the development of the League of Workers as a Christian organisation. After the Bolsheviks removed Muckermann from Vilnius by force, Poles who were dominant in church spheres gradually took control of the League. The Lithuanians, even together with the more influential Belarusians in the leadership of the League, were unable to stop this trend. On the other hand, after Muckermann's arrest, no efforts in that direction could be seen. However, it would be completely shortsighted to overlook changes in the provisions of the League and its stature after the event mentioned, and even more to consider the League a Polish organisation from its very creation.

It is even possible to distinguish three periods in the activities of the League. First, the period of Muckermann's leadership, as already mentioned, was marked by national impartiality, an emphasis on Christian values, and the consolidation of the public. In the second period, which lasted from Muckermann's arrest until the entry of the Poles into Vilnius in April 1919, the League turned from being a peaceful Christian organisation into a semi-legal gathering of opposition-minded people, also ready for armed resistance against the Bolsheviks. Because the Poles impressed most with the potential of their power, moreover, their representatives took over the leadership of the League. The League went with them, and played a significant role in the capture of Vilnius. After that, in the third period, under the Polish government, we can consider the League to be a real Polish organisation, which, however, increasingly contrasted with the realities of the times, and lost the functions for which it had been established, and functioned as a symbol of resistance to Bolshevism tolerated by the government.

Muckermann himself, meanwhile, in later stages of his life, confirmed his reputation as an extraordinary personality. After leaving Bolshevik captivity in an original way and excelling in the Soviet-Polish negotiations at Mikashevichy, he became one of the most prominent Catholic leaders in Weimar Germany. In the years of Nazi rule, he became famous as a symbol of the Catholic opposition to the regime. 


\section{Author Details}

Edmundas Gimžauskas is a doctor of humanities and a researcher in the 20th Century History Department of the Lithuanian Institute of History. His main academic interests are Lithuania ethnopolitical history in the first half of the 20th century, preparing the publication of 20th-century sources of Lithuania's history.

Address: Lietuvos istorijos institutas, Kražių g. 5, Vilnius, LT-01108

Email: e.gimzauskas@yahoo.com

KUNIGO FRIEDRICHO MUCKERMANNO VEIKLA 1918-1919 M. VILNIUJE: REIKŠMINGA PARAIŠKA PILIETINĖS VISUOMENĖS LINK? (KRIKŠČIONIŠKOS DARBININKŲ LYGOS FENOMENAS)

Santrauka

\section{EDMUNDAS GIMŽAUSKAS}

Vokiečių kunigo Friedricho Muckermanno veikla Vilniuje yra vienas tų atvejų, kai neeilinè asmenybè dèl savo asmeninių savybių ir pastangų daro lemiamą ịtaką visuomeninio proceso raidai telkdama gausų pasekèjų būrị. Dèl karo aplinkybių atsidūręs Vilniuje, buvęs vokiečių kareivių kapelionas matė čia plačią erdvę savęs profesiniam ir pasaulèžiūriniam realizavimui, be to, jautè, kad vietinei visuomenei reikia tokios veiklos. Prielaidos F. Muckermanno pradètai socialinei veiklai susidare XX a. pradžioje, kai pagreitị igavo katalikybès transformavimasis iš konfesinès ị visuomeninę kategoriją, ir iš šio reiškinio išaugo visuotinè krikščioniška socialinè veikla. Su F. Muckermanno veiklos pradžia sutapo kunigo Jurgio Matulaičio, žymiojo socialinės veiklos propaguotojo, skyrimas Vilniaus vyskupu. Naujasis vyskupas tapo F. Muckermanno globeju ir bendraminčiu.

Atejjus bolševikams itin aktualus pasidarè socialinis klausimas. Vokiečių kunigui Darbininkų lygą teko kurti ekstremaliomis sąlygomis. Tačiau, kita vertus, bolševikai nuslopino katalikybès tapatinimo su lenkybe tendenciją. Tad buvo lengviau ịvairių tautybių katalikus konsoliduoti F. Muckermanno vadovaujamoje organizacijoje. Vokiečiu jèzuito sèkmingos veiklos pradžia domino tautinių judèjimų veikèjus Vilniuje. Jie, suvokdami kunigo pradètos kultūrinès socialinès konsolidacijos perspektyvą peraugti i politinę istorinio LDK valstybingumo pagrindu, natūraliai siekė daryti įtaką Lygai. Kadangi istorinio valstybingumo realizavimas XX a. sąlygomis ịsivaizduojamas tik kaip pilietinis apsisprendimas, i F. Muckermanno ir jo bendražygių veiklą galima žvelgti ir kaip ị visuomeninị poslinkị pilietiškumo link. 
Kai bolševikai suemė F. Muckermanną, Lyga ne tik perèjo i lenkų rankas, bet ir pati organizacija pasuko radikalaus pasipriešinimo linkme. Kadangi tolesnè organizacijos raida itin priklausė nuo Vilniaus dvasininkijos, kurioje aiškiai dominavo lenkai, pozicijos, šie ir perèmè įtaką. Lietuviai, netgi kartu su baltarusiais, nesugebèjo rimčiau dèl šios įtakos pakovoti.

Lygos nariai aktyviai prisidejo prie Lenkijos kariuomenès, 1919 m. balandị užèmusios Vilnių. Nuo to laiko organizaciją galima laikyti lenkiška, o šito jokiu būdu negalima pasakyti apie F. Muckermanno vadovautą Lygą. Vèliau, Lenkijos valdžios laikotarpiu, kuo toliau, tuo labiau Lyga darèsi anachronizmu, nes uždavinius, dèl kurių buvo kurta, perèmè grynai lenkiškos kilmès organizacijos. Valdžia neskubèjo organizacijos paleisti, nes ji tapo pasipriešinimo bolševizmui simboliu.

Pats F. Muckermannas tolesneje savo biografijoje tik sustiprino neeilinès asmenybès ịvaizdị. Ištrūkęs iš bolševikų nelaisvès ir sublizgèjęs lenkų-sovietų derybose Mikaševičiuose 1919 m. pabaigoje, tarpukario Vokietijoje jis tapo vienu žymiausių katalikų veikejjų, krikščioniškojo pasipriešinimo nacizmui simboliu. 